Revue bibliographique pour le domaine irano-aryen

\title{
Ehsan Shavarebi, Sajad Amiri Bavandpour. "A Note on the Temple of Anāhīd-Ardašīr at Estakhr and the Martyrdom of Abbot Baršebyā"
}

\section{Domiziana Rossi}

\section{(2) OpenEdition Journals}

Electronic version

URL: https://journals.openedition.org/abstractairanica/52102

DOI: 10.4000/abstractairanica.52102

ISSN: 1961-960X

Publisher:

CNRS (UMR 7528 Mondes iraniens et indiens), Éditions de l'IFRI

\section{Electronic reference}

Domiziana Rossi, "Ehsan Shavarebi, Sajad Amiri Bavandpour. "A Note on the Temple of Anāhīd-Ardašîr at Estakhr and the Martyrdom of Abbot Baršebyä"', Abstracta Iranica [Online], Volume 42-43 | 2021, document 14, Online since 30 December 2020, connection on 25 December 2022. URL: http:// journals.openedition.org/abstractairanica/52102 ; DOI: https://doi.org/10.4000/abstractairanica. 52102

This text was automatically generated on 25 December 2022.

All rights reserved 


\title{
Ehsan Shavarebi, Sajad Amiri Bavandpour. "A Note on the Temple of Anāhīd-Ardašīr at Estakhr and the Martyrdom of Abbot Baršebyā"
}

\author{
Domiziana Rossi
}

\section{REFERENCES}

Ehsan Shavarebi, Sajad Amiri Bavandpour. "A Note on the Temple of Anāhīd-Ardašīr at Estakhr and the Martyrdom of Abbot Baršebyā", Dabir: Digital Archive of Brief notes and Iran Review 7, 2020, p. 168-174

1 After publishing "The Temples of Anāhīd at Estakhr (Southern Iran): Historical Documents and Archaeological Evidence" (2018) in Juraj Belaj et al. (ed.). Sacralization of Landscape and Sacred Places, (Zbornik Instituta za Arheologiju Serta Instituti ArchaeologiciKknjiga, 10), Zabreb p. 179-194), Shavarebi was contacted by Amiri Bavandpour who offered an important piece of information about the Anāhīd temples at Estakhr. These two temples are mentioned in Kerdī's inscription at Ka'aba-ye Zardošt. The older temple, i.e., the Fire of Anāhīd the Lady, may have been originally founded by Artaxerxes II (r. 404-359 BCE) and Shavarebi proposes the northern building of the 'Frataraka Complex' as its most probable location. This temple was replaced in post-Achaemenid times by a newer building, known as the 'Window Temple', identified as the 'House of Fire of Anāhìd'.

2 Shavarebi argues for an identification of the second temple, i.e., the Fire of AnāhīdArdašĩr, with the 'House of Fire of Ardašǐr', which was presumably located within the bounds of the Sasanian city of Estakhr. An account in the Syriac hagiographical text, 
the Martyrdom of Abbot Baršebyā, found by Amiri Bavandpour, seems to confirm this interpretation. Although it is not clear which ones of the temples the extract refers to, the location is undoubtedly inside the city and not somewhere in the surroundings. New excavations in the area are much needed to provide answers on the ancient Estakhr.

However, the fact that there is evidence of another intramural temple means that the Takht-e Nešin of Ardašīr-Xwarrah and the Anāhīd temple at Bīšāpūr are not unique anymore. In the absence of archaeological data, information extrapolated by textual sources play a key role for our understanding of Sasanian times.

\section{AUTHORS}

DOMIZIANA ROSSI

Cardiff University 